\title{
BREASTMILK AND COVID-19
}

\author{
ANNE SÜTÜ VE COVID-19
}

\author{
Gülbin GÖKÇAY'1,2 (D), Gonca KESKINDEMIRCi2,3 (D)
}

\begin{abstract}
${ }^{1}$ Istanbul University, Institute of Child Health, Department of Social Pediatrics, Istanbul, Turkey
${ }^{2}$ Istanbul University, Istanbul Faculty of Medicine, Department of Child Health and Diseases, Department of Social Pediatrics, Istanbul, Turkey ${ }^{3}$ Istanbul University, Institute of Health Sciences, Institute of Child Health, Social Pediatrics Doctoral Program, Istanbul, Turkey
\end{abstract}

ORCID IDs of the authors: G.G. 0000-0003-1042-0407; G.K. 0000-0003-1797-2802

Cite this article as: Gokcay G, Keskindermirci G. Breastmilk and Covid-19. J Ist Faculty Med 2020;83(3):286-90.

doi: 10.26650/IUITFD.2020.0025

\begin{abstract}
After the New Corona Virus epidemic emerged in China at the beginning of December 2019, authorities announced the appearance of cases in our country in March 2020. This epidemic reminds us of the importance of preventive healthcare. Breastfeeding is very important for child health. The anti-infective and immunomodulatory properties of breast milk play an important role in protection against infections. Passive immunity is provided especially by the high secretory IgA concentration and other antipathogen factors in breastmilk. During emergency situations, protection and promotion of breastfeeding is very important. The COVID-19 pandemic is also an emergency situation, and it is recommended that mothers should continue breastfeeding or giving expressed milk by wearing a mask, and taking necessary hygiene measurements during this epidemic.
\end{abstract}

Keywords: COVID-19, breastfeeding, human milk

\section{ÖZET}

Aralık 2019 başında Çin'de ortaya çıkan Yeni Korona Virüs salgını Mart 2020 tarihinde ülkemizde görülmeye başlandıktan sonra koruyucu sağlık hizmetlerinin önemi bir kez daha ortaya çıkmıştır. Olağanüstü koşullarda sağlığın korunması ve sürdürülmesinde anne sütü ile beslenme çok önemlidir. Bu salgın da bir olağanüstü durumdur. Enfeksiyonlardan korunmada anne sütünün anti-infektif ve immunmodülator etkisi öne çıkmaktadır. Anne sütü içeriğinde bulunan özellikle yüksek salgısal IgA ve diğer biyoaktif madddeler ile pasif doğal bağışıklık sağlanmaktadır. COVID-19 pandemisinin yaşandığı bu dönemde anne sütü ile beslenmenin sürdürülmesi ve desteklenmesi enfeksiyondan korunmak için gereklidir. Mevcut bilimsel verilere göre temas ya da enfeksiyon varlığında annenin maske takarak, gereken hijyen kurallarını sağlayarak emzirmeye ya da sağarak anne sütü vermeye devam etmesi önerilmektedir.

Anahtar Kelimeler: COVID-19, emzirme, anne sütü

\section{INTRODUCTION}

The COVID-19 pandemic, first recognized in China in early December 2019 by an increasing awareness of clustering cases of pneumonia, made its debut in Turkey in March 2020. This, as expected, led to many questions being addressed to paediatricians, such as "How are we going to protect our infants and children from this disease?", "What can we do to strengthen their immunity?" "Can I breast-feed if I am sick?". In this paper, we will try to deal with questions related to breast feeding during an epidemic, especially with reference to COVID-19.

\section{The epidemiology of the novel corona virus (SARS-CoV-2 OR 2019-nCOV) infection and clinical presentation}

The COVID-19 or SARS-CoV-2 infection first appeared in China in December 2019. The majority of patients were noted to be between 30 and 79 years of age (1). Thanks to the intense measures for isolation and quarantine, the epidemic was brought under control in China after a period of 3 months, by which time, March 2020, the disease had emerged in several countries, including Turkey, and the World Health Organization (WHO), evaluating the findings, declared the situation to be a pandemic (2). It

Corresponding author/iletişim kurulacak yazar: drgulbin@gmail.com

Submitted/Başvuru: 23.03.2020 • Accepted/Kabul: 23.03.2020 • Published Online/Online Yayın: 23.03.2020

(C)Telif Hakkı $2020 \mathrm{~J}$ Ist Faculty Med - Makale metnine jmed.istanbul.edu.tr web sayfasından ulaşılabilir.

CCopyright 2020 by J Ist Faculty Med - Available online at jmed.istanbul.edu.tr 
was reported that by 10 March 2020, there were 110,000 infected cases and 4,000 deaths $(2,3)$. In an evaluation conducted in China on 72,314 cases, the proportion of cases younger than 10 years was found to be $1 \%$ (1). It was reported that the infection follows a milder course in children $(1,3)$. Contamination from human to human occurs by direct air contact. Clinical symptoms develop similar to any upper respiratory infection. The severity of the clinical state depends on the immune state of the patient. Infectivity starts a few days before the development of clinical symptoms. Breast milk has not been reported as a source of infection $(4,5)$. In an article from China early in February 2020, it was mentioned in a vague way that a mother who has tested positive or who was suspected of having COVID-19 should not breast feed her baby, but that she could breast feed if her test was negative (6). On the other hand, the paper did not report any findings which indicated infection via breast milk. Meanwhile, Chen et al (5) performed a postnatal study of the amniotic fluid, cord blood, breast milk and throat scraping on 6 of 9 pregnant women who had tested positive in their last trimester of pregnancy and found negative test results for SARSCoV-2. Samples were not available in three of the mothers (5). These results indicate that there was no contagion by breast milk. Available data on these cases will increase in time. WHO as well as the Royal College of Paediatrics and Child Health have evaluated the available data on the properties of similar respiratory viruses and breast milk with relation to COVID-19 data and have concluded that there should be no concerns about breast feeding $(4,7)$.

As per WHO instructions for all emergency situations, in a COVID-19 epidemic, it is also important to implement the principles of preventive health care measures. Breast feeding and immunization procedures are at the top of the list among these measures (7). Due to the singular nutritional properties of human milk, alongside with its immunological, anti-infective and immunomodulator properties, promotion and protection of breast feeding during epidemics is of utmost importance $(8,9)$.

\section{Immunoprotective properties of breast milk}

There has been an abundance of scientific studies, published within the past five years, on the immunological properties of human milk and their effectiveness. The effectiveness of these properties increase with exclusive breast feeding in the first 6 months of life and during the course of breast feeding (9).

The protective components of breast milk show an interactive effect in an in vivo environment. However, it is best to consider these components in two groups, namely cellular and humoral. The cellular components of colostrum and breast milk are shown in Table 1. Active leucocytes are naturally present in human milk and their number decreases after the first months of life. The colostrum con-
Table 1: Cellular components of breast milk (9)

Leucocytes
Macrophages
Polymorphonuclear leucocytes
Lymphocytes
Stem cells

tains one million cells per $\mathrm{mL}$. Breast milk contains both $\mathrm{T}$ and $\mathrm{B}$ lymphocytes, with $\mathrm{T}$ lymphocytes in the majority. While all immunoglobulin groups are present in human milk, secretory IgA is the major one. Secretory IgA promotes mucosal immunity and plays a primary role in protection from pathogenic microorganisms. Colostrum contains high concentrations of $\operatorname{lgA}$, and with continued breast feeding, these levels persist in the first 12-24 months of life; the antipathogenic properties of IgA for some organisms even increase during this period (10). Secretory IgA provides a passive immunity for respiratory infections as well as for infections of the intestinal tract. It has been shown that breast-feeding leads to a decrease of $53 \%$ in infants presenting with upper respiratory infections and to a decrease of $27 \%$ in those presenting with diarrhea (11). Karabayir et al reported the case of an infant whose mother had clinical signs of varicella including presence of an active lesion on her breast as well as a positive Varisella Zoster Virüs (VZV) DNA finding in her milk, who had continued to be breast fed, but showed no signs or symptoms of chicken pox. The authors concluded that these results were due to the immunity provoked by the varicella infection in the mother and the transfer of the antibodies to the infant (12).

The nutritional levels of a person do not affect the immunoglobulin level of human milk. These levels are essentially similar in well-fed and in malnourished women (13). There are antibodies and some antipathogenic factors for certain viruses in breast milk as shown in Table 2. These antibodies are transferred to the infant and provide protection. A breast feeding mother who acquires an infection produces proteins which protect her and which also are transferred to her infant, thus protecting her infant from acquiring the infection. The same process applies practically to all viral infections. Also, several substances other than antibodies have a role in the antiviral properties of human milk.

Bioactive structures with important immunological properties are also present in human milk (Table 3). The bifidus factor promotes the growth of a probiotic microorganism, namely, of Lactobacillus bifidus, in the intestinal flora of the infant. Lactobacillus bifidus has protective immunological properties. It stimulates antibody production and enhances phagocytosis. Lysozyme is an antimicrobial sub- 
Table 2: Immunologically and pharmacologically active components for some viral infections observed in breast milk (9)

\begin{tabular}{|c|c|c|c|}
\hline $\begin{array}{l}\text { Immunoglobulin/ } \\
\text { antiviral factor }\end{array}$ & Viral infection & $\begin{array}{l}\text { Immunoglobulin/ } \\
\text { antiviral factor }\end{array}$ & Viral infection \\
\hline \multirow[t]{13}{*}{ Secretory IgA } & Enteroviruses & $\lg M, \lg G$ & CMV \\
\hline & Poliovirus types 1,2,3 & & RSV \\
\hline & Some Coxsackievirus types & & Rotavirus \\
\hline & Echovirus types 6 and 9 & & Rubella \\
\hline & Herpesvirus & $\lg E$ & Parvovirus B19 \\
\hline & CMV & Lipids & Herpes simplex \\
\hline & Herpes simplex virus & Macromolecules & Herpes simplex \\
\hline & HIV & & Coxsackievirus B4 \\
\hline & RSV & & CMV \\
\hline & Rubella & & Rotavirus \\
\hline & Rotavirus & a-2 macroglobulin & Influenza \\
\hline & Measles & & Parainfluenza \\
\hline & Norovirus & a-1 antitripsin & Rotavirus \\
\hline
\end{tabular}

Table 3: Some bioactive substances in breast milk (9)

Bifidus factor
Lysozyme
Lactoferrin
Interferon
Complement
Vitamin B12 binding protein
Glycans and oligosaccharides
Interleukins
Nucleotides

stance which is heat resistant and also acid resistant. In lactating mothers, lysozyme concentration in milk increases during the course of the $12^{\text {th }}$ and $24^{\text {th }}$ months of breastfeeding. Human milk also contains lactoferrin, which is an iron binding protein, a substance with an inhibitory action on the reproduction of viruses and of many pathogenic microorganisms in the intestines. Lactoferrin is resistant to proteolysis and has been reported to have anticancer properties (9). Interferon, a substance with marked antiviral properties, is produced by the natural killer cells and T cells present in human milk. Glycans and oligosaccharides, substances with complex carbohydrate structures, are reported to have antipathogenic, immunomodulator, antiinflammatory and prebiotic effects $(14,15)$.

Breast feeding protects the mother from many diseases and also has a balancing effect on her mental health
$(8,9)$. In the course of breast feeding, oxytocin increases in human blood. This hormone is reported to have a protective effect from depression and its pacifying effect on the mother's psyche has been observed (9). Thus, this hormone enhances the resistance of the mother to adverse conditions such as epidemics.

Considering the protective qualities of breast milk and of lactation in human health, the importance of continuation of breast feeding in epidemics and other extraordinary conditions cannot be overstressed. In addition to its singular nutritional qualities and its protective effect from diseases, human milk is the most hygienic as well as the most natural and low cost food for the infant.

At present, reports from the Chinese experience constitute our most important source of epidemiological data on COVID-19 infection. The infection is known to spread by respiratory secretions. Infection via breast milk has not been reported $(4,5,16,17)$. In the light of the experience gained from similar viral infections such as SARS, in infants whose mothers are infected with SARS-CoV-2 or are suspected to have this infection, continuation of breastfeeding is reported to be the most suitable approach $(16,17)$.

\section{Principles related to breast feeding during the COVID-19 epidemic}

WHO advocates exclusive breast feeding for all infants in the first 6 months of life and the continuation of breast feeding with complementary feedings until the infant is at least two years old. The importance of continuation of breast feeding during emergencies such as epidemics is also stressed (18). Many scientific sources have stressed 
the importance of breast feeding during this COVID-19 epidemic $(4,7,16,17)$. The recommendations of these scientific organizations and of WHO are summarized below:

\section{Breast feeding should not be discontinued during} epidemics: Mothers who are thinking of ending breast feeding should postpone this decision. Thus the infant will continue to receive the immunologic components present in human milk.

It should not be forgotten that depriving the infant from being breast fed for reasons such as a positive test result in the mother, will expose him/her to great risks. Such an infant will be deprived of preventive proteins produced actively by the mother through exposure to COVID-19, which are also transmitted to her milk, and also of immunity related substances naturally present in human milk (Tables 1, 2, 3), and thus the infant will be at risk of contracting COVID-19 and all infectious diseases.

Breast feeding should not be discontinued due to the mother's contact with a person with a diagnosis of COVID-19 infection: In such a situation the measures listed below should be taken and breast feeding continued:

1. The mother should use a mask while breast feeding or while expressing her milk,

2. Before feeding her baby, the mother should wash her hands in an effective way (washing for about 20 seconds all areas covering the ventral, dorsal and interdigital surfaces of the hands, the palms and areas extending to the wrists, followed by rinsing and drying with a towel used only once). Rings and bracelets need to be taken off as they will hinder effective hand washing,

3. The room should be ventilated at frequent intervals,

4. All clothing should be washed using detergents, at water temperatures of $60-90^{\circ} \mathrm{C}$,

5. The mother should consume plenty of liquids, be on a balanced diet and get enough sleep.

\section{A breast feeding mother receiving treatment at home should not be separated from her infant: WHO and many international scientific organizations advise that in this situation, the infant and the mother should not be sep- arated and that breast feeding should be continued along with observation of hygienic measures $(4,7,16,17,19)$.}

WHO's suggestions for the home care of patients with mild symptoms can be summarized as follows: Educating the patient and the household on the provision of hygienic measures, including measures to prevent contagion. To this end, the patient should be isolated in a well ventilated environment, her mobility in the house should be limited, her room should not be shared by other household members and if this is not possible, they should remain at a distance of at least one meter from the patient. Breast feeding should be continued, but the mother is advised to wear a mask and pay attention to hand hygiene during contact with her infant. Other WHO recommendations include the limitation of numbers of care givers, attention to hand hygiene following contact with the patient or her belongings, and if possible, the use of alcohol based hand disinfectants (19).

Measures to ensure breast feeding in infants whose COVID-19 (+) mothers are hospitalized: The decision to isolate mothers from their infants should be left to the hospital team. However, if the team decides to leave the COVID-19 (+) mother and her baby in the same room, the mother should be advised not to kiss her baby and to adhere strictly to hygienic rules. The distance between the baby's cradle and the mother's bed should be at least two meters apart $(16,17)$. If there is a need for the mother and infant to be separated temporarily, the infant should continue to receive expressed breast milk. It is preferable that instead of a bottle, the infant be fed by spoon or cup. Hygienic measures, including the use of disinfectants containing 60-95\% alcohol, need to be observed during the collection of breast milk. At this stage, the safety of the drugs given to the mother from the perspective of breast feeding should also be checked from official sources and scientific publications $(20,21)$.

\section{CONCLUSION}

In the light of existing scientific data, we can conclude that contact with or infection from COVID-19 should not lead to cessation of breast feeding. In view of the infant's health, the continuation of breast feeding and application of routine immunization procedures are of utmost importance.

Peer Review: Externally peer-reviewed.

Author Contributions: Conception/Design of Study- G.G., G.K.; Drafting Manuscript- G.G., G.K.; Critical Revision of Manuscript- G.G., G.K.; Final Approval and Accountability- G.G., G.K; Supervision- G.G., G.K.

Conflict of Interest: Authors declared no conflict of interest.

Financial Disclosure: Authors declared no financial support.

Hakem Değerlendirmesi: Dış bağımsız.

Yazar Katkıları: Çalışma Konsepti/Tasarım-G.G., G.K.; Yazı Taslağı- G.G., G.K.; Içeriğin Eleştirel İncelemesi- G.G., G.K.; Son Onay ve Sorumluluk- G.G., G.K; Süpervizyon- G.G., G.K.

Çıkar Çatışması: Yazarlar çıkar çatışması beyan etmemişlerdir.

Finansal Destek: Yazarlar finansal destek beyan etmemişlerdir. 


\section{REFERENCES}

1. Wu Z, McGoogan JM. Characteristics of and important lessons from the coronavirus disease 2019 (COVID-19) outbreak in China: summary of a report of 72314 cases from the Chinese Center for Disease Control and Prevention. JAMA, 2020 February 24 (online). [CrossRef]

2. WHO Director-General's opening remarks at the media briefing on COVID-19 - 11 March 2020. Erişim: https:// www.who.int/dg/speeches/detail/who-director-general-sopening-remarks-at-the-media-briefing-on-covid-19---11march-2020. Son Erişim: 20.3.2020.

3. Lu X, Zhang L, Du H, Zhang J, Li YY, Qu J, et al. SARS-CoV-2 infection in children [published online ahead of print, $2020 \mathrm{Mar}$ 18]. N Engl J Med. 2020;10.1056/NEJMc2005073. [CrossRef]

4. Royal College of Paediatrics and Child Health. COVID-19guidance for paediatric services. RCPCH. London. Erişim: https://www.rcpch.ac.uk/sites/default/files/generated-pdf/ document/COVID-19---guidance-for-paediatric-services. pdf. Son erişim: 20.3.2020

5. Chen H, Guo J, Wan, C, Luo F, Yu X. Zhang,W, et al. Clinical characteristics and intrauterine vertical transmission potential of COVID-19 infection in nine pregnant women: a retrospective review of medical records. The Lancet 2020; 395(10226):809-15. [CrossRef]

6. Wang L, Shi Y, Xiao T, Fu J, Feng X, Mu D, et al. Chinese expert consensus on the perinatal and neonatal management for the prevention and control of the 2019 novel coronavirus infection. Ann Transl Med 2020;8(3):47. [CrossRef]

7. World Health Organization Q\&A on COVID-19, pregnancy, childbirth and breastfeeding.World Health Organization. Geneva Erişim: https://www.who.int/news-room/q-a-detail/ q-a-on-covid-19-pregnancy-childbirth-and-breastfeeding. Son erişim: 20.3.2020

8. Gökçay $G$, Keskindemirci $G$. Anne sütünün önemi. Telatar $B$, editör. Aile Hekimliğinde Anne Sütünün Anne ve Bebek Sağlı̆̆ı Açısından Önemi. 1. Baskı. Ankara: Türkiye Klinikleri; 2019. p.1-7.

9. Lawrence R A, Lawrence RM. Breastfeeding: A Guide for the Medical Profession. Eighth Edition, Philadelphia: Elsevier Yayınları 2016. p.146-193.
10. Goldman AS, Goldblum RM, Graza C. Immunologic components in human milk during the second year of lactation. Acta Paediatr Scand 1983;72:461-2. [CrossRef]

11. Quigley MA, Kelly YJ, Sacker A. Breastfeeding and hospitalization for diarrheal and respiratory infection in the United Kingdom Millennium Cohort Study. Pediatrics 2007;119(4):e837-e842. [CrossRef]

12. Karabayir N, Yaşa B, Gökçay G. Chickenpox infection during lactation. Breastfeed Med 2015;10(1):71-2. [CrossRef]

13. Reddy V, Bhaskaram C, Raghuramula N, Jagadeesan V. Antimicrobial factors in human milk. Acta Paediatr Scand 1977;66:229-32. [CrossRef]

14. Morrow AL, Ruiz-Palacios GM, Altaye M, Jiang X, Guerrero $\mathrm{ML}$, Meinzen-Derr JK, et al. Human milk oligosaccharides are associated with protection against diarrhea in breastfed infants. J Pediatr 2004;145(3):297-303. [CrossRef]

15. Andreas N J, Kampmann B, Le-Doare KM. Human breast milk: A review on its composition and bioactivity. Early Hum Dev 2015;91(11):629-35. doi: 10.1016/j.earlhumdev. 2015.08.013. Epub 2015 Sep 12. [CrossRef]

16. Academy of Breastfeeding Medicine Statement On Coronavirus 2019 (COVID-19). Academy of Breastfeeding Medicine. Erişim: https://www.bfmed.org/abm-statementcoronavirus. Son erişim: 20.03.2020.

17. Center for Disease Control. https://www.cdc.gov/ coronavirus/2019-ncov/prepare/pregnancy-breastfeeding. html. Son erişim: 21.03.2020.

18. World Health Organization, Guiding principles for feeding infants and young children during emergencies. 2004, Geneva WHO/NHD/99.10

19. World Health Organization. Home care for patients with COVID-19 presenting with mild symptoms and management of their contacts: interim guidance, 17 March 2020 (No. WHO/nCov/IPC/HomeCare/2020.3).

20. Drugs and Lactation Database (LactMed) Erişim: https:// www.ncbi.nlm.nih.gov/books/NBK501922/ Son erişim: 20.3.2020

21. Jones W. Breastfeeding and Medication. 2013 Routledge London. [CrossRef] 